\title{
EFFECTS OF NITRATE AND LABILE CARBON ON DENITRIFICATION OF SOUTHERN TEMPERATE FOREST SOILS
}

\author{
Cecilia A. Pérez ${ }^{*}$, Martín R. Carmona ${ }^{2}$, José M. Fariña1 ${ }^{1}$ and Juan J. Armesto ${ }^{1,2}$
}

\begin{abstract}
The pressure for anthropogenic land use changes and logging of temperate forests in southern Chile is rapidly increasing, with its potentially high impacts on the capacity of soils to retain important limiting elements. We tested the hypotheses that logging increases the denitrification rates and nitrate and $\mathrm{C}$ limitation of denitrifiers activity would be higher in soils of unlogged, old-growth forests than in soils of logged forests. Potential denitrification rates were estimated by the acetylene inhibition assay in intact soil cores in laboratory short-term aerobic incubations using the following treatments: $0.7 \mathrm{mmol} \mathrm{NO}_{3}-\mathrm{N}$ addition, the same nitrate addition plus $23.3 \mathrm{mmol} \mathrm{C}$-glucose, and controls (no additions) with and without $10 \% \mathrm{v} / \mathrm{v}$ acetylene. Forest logging did not significantly change soil nitrate content and $\mathrm{C}$ lability (e.g. soil $\mathrm{C} / \mathrm{N}$ ratio). A nested two-factor ANOVA for repeated measures showed that denitrification was enhanced by nitrate plus labile $\mathrm{C}$ additions in both forests, suggesting that in both logged and unlogged forests labile $\mathrm{C}$ and nitrate limit denitrifiers activity. Increases were up to one order of magnitude when glucose was added to nitrate treated soils; from $373 \pm 113$ to $3353 \pm 451 \mu \mathrm{g} \mathrm{N}_{2} \mathrm{O}-\mathrm{N} \mathrm{m}^{-2} \mathrm{~d}^{-1}$ in the unlogged, oldgrowth forest and from $1369 \pm 941$ to $12192 \pm 7474 \mu \mathrm{g} \mathrm{N}_{2} \mathrm{O}-\mathrm{N} \mathrm{m}^{-2} \mathrm{~d}^{-1}$ in the logged forest. We conclude that, denitrification would be enhanced in logged forests in the longer term due to a greater nitrate and labile $\mathrm{C}$ availability of both in disturbed soils.
\end{abstract}

Key words: acetylene inhibition assay, lowland evergreen forests, selective logging, nitrogen availability.

\section{INTRODUCTION}

Soils of unpolluted, old-growth temperate forests in Chile and Argentina present a high ratio of net nitrification in relation to net mineralized N; either potential (Pérez et al., 1998; Satti et al., 2003) or in situ (Pérez et al., 1998; Decker and Boerner, 2003). However nitrate pools in forest soils and nitrate losses to stream waters are extremely low because of a high $\mathrm{N}$ retention in soil organic matter (Perakis and Hedin, 2001). The almost complete transformation of nitrate to ammonium by dissimilatory nitrate reduction has been postulated as a mechanism of $\mathrm{N}$ retention within an old-growth Andean forest ecosystem in this region (Huygens et al., 2007). However, there is little information about the magnitude of denitrification, i.e. microbial reduction of reactive $\mathrm{N}$ oxides to nitrous oxide and elemental $\mathrm{N}$ in these forests (Pérez et al.,

${ }^{1}$ Pontificia Universidad Católica de Chile, Centre for Advanced Studies in Ecology \& Biodiversity (CASEB), Alameda 340, Santiago, Chile.*Corresponding author (cperez@bio.puc.cl).

${ }^{2}$ Instituto de Ecología y Biodiversidad, Casilla 653, Santiago, Chile. Received: 02 March 2009.

Accepted: 03 July 2009.
2003). During denitrification $C$ acts as an electron donor and nitrate as an electron acceptor, so denitrifiers are active in $\mathrm{C}$-rich and water saturated soils, where nitrate serves as electron acceptor instead of oxygen. In the temperate region of the Northern Hemisphere, it is well documented for conifer, hardwood or riparian forests that the addition of nitrate and labile $\mathrm{C}$ to soils increases the rates of denitrification (Robertson et al., 1987; Ashby et al., 1998; Henrich and Haselwandter, 1997; Regina et al., 1998; Jordan et al., 1998; Mohn et al., 2000; Laverman et al., 2001; Wallenstein et al. 2006). However, such studies have not been conducted in comparatively less polluted southern temperate forests where nitrate retention in soils is remarkably high.

Two anthropogenic factors that can drastically disrupt $\mathrm{N}$ retention mechanisms in unpolluted southern temperate forests: 1) the global increase in atmospheric reactive $\mathrm{N}$ from neighbouring agricultural activities that increase the emissions of ammonia (Godoy et al., 2005) and, 2) the pressure of land use change from forests to agriculture and exotic tree plantations (Armesto et al., 2009). Welldocumented effects of such alterations are reported for air-polluted northern temperate forests, especially in areas that have a long history of logging and agricultural land 
use. The evidence shows that forest logging increases $\mathrm{N}$ availability through higher rates of mineralization (Reynolds et al., 2000; Thibodeau et al., 2000; Hope et al., 2003; Lindo and Visser, 2003; Inagaki et al., 2008) and decomposition (Prescott, 1997; Brais et al., 2002), leading to increased availability of labile $\mathrm{C}$ (Chatterjee et al., 2008) and higher denitrification (Robertson and Tiedje, 1988). However, the effects of altering the inputs of reactive $\mathrm{N}$ and land use change in $\mathrm{N}$ transformations are less understood in southern temperate forests, where $\mathrm{N}$ is strongly limiting for tree growth (Perakis and Hedin, 2001; Vann et al., 2002; Satti et al., 2003; Diehl et al., 2008), and soils are dominated by recalcitrant forms of C, as indicated by the relatively high soil $\mathrm{C} / \mathrm{N}$ ratios (Pérez et al., 2009). Such analysis is relevant because one of the important microbial transformations in the context of global change is denitrification, as it may counteract eutrophication in aquatic ecosystems and also may be a significant source of $\mathrm{N}_{2} \mathrm{O}$, an important greenhouse gas.

In the present study we tested the hypotheses that increases of soil $\mathrm{N}$ availability and labile $\mathrm{C}$ (i.e. lower soil $\mathrm{C} / \mathrm{N}$ ratios) following logging of southern temperate forests should enhance denitrification rates in soils, and secondly, under nitrate plus glucose addition denitrification should be more enhanced in unlogged forests, because of the postulated stronger limitation of these elements. The main objective of this work was to evaluate the effects of soil available $\mathrm{N}$ as nitrate and $\mathrm{C}$ as glucose for denitrification rates using short-term aerobic laboratory incubations of soils of logged and unlogged old growth forests from southern Chile. Although lab incubations are only indicative of processes occurring in the field, we expect that our data offers insights into the effects of logging on $\mathrm{N}$ transformations and allows us to make more precise predictions about $\mathrm{N}$ dynamics in southern temperate forests.

\section{MATERIAL AND METHODS}

\section{Study area}

Soils were collected from evergreen rain forests in central Chiloé Island $\left(42^{\circ} 37^{\prime} \mathrm{S}, 73^{\circ} 46^{\prime} \mathrm{W}\right)$, Chile. In this region lowland, old-growth rainforests are dominated by broad-leaved evergreen tree species, mainly "tepa" Laureliopsis philippiana (G. Looser) Schodde and different Myrtaceae species (Gutiérrez et al., 2009). The study sites are located on the foothills of the Coastal Range, between 100-200 m.a.s.l. Soils are well drained, with a high content of organic matter in the $A_{h}$ horizon (ca. 50\%). Soil texture belongs to silty-loam. Soil type belongs to Cambisols.

Within an area of $c a .2 \mathrm{~km}^{2}$ a small watershed was selected which was logged $11 \mathrm{yr}$ ago with selective logging, i.e., removal of $50 \%$ of all the basal area of the stand. An adjacent unlogged old growth forest of $c a .300$ yr old was sampled as control. Detailed descriptions of the structure and dynamics of this old-growth forest are given by Gutiérrez et al. (2009). Selective logging required a silvicultural plan approved by CONAF (Chilean Forest Service). Selective cut of L. philippiana individuals, $>50 \mathrm{~cm}$ diameter at breast height, from an area of about 100 ha left behind $35-40 \%$ of the original canopy cover. Timber of this species is used for industrial production of wooden panels. It is worth mentioning that selective logging was applied only to one watershed in the study area, and therefore a suitable replicate of this treatment was unavailable for the same soil and topography. In order to capture as much spatial variability as possible, we sampled across the complete logged area, avoiding the edge effects.

\section{Experimental design}

In each forest three springs were selected as reference for sampling point location. The reference springs were about 150-200 m from each other. From each, a sample point was located $12 \mathrm{~m}$ away following the contour line, perpendicular to the springs, and a second point was sampled in the opposite direction. In total there were six sample points per forest (control and logged). Seasonally, from April 2005 until January 2008 (11 sampling dates), pointing each point we obtained samples of surface mineral soil $\left(A_{h}, 0-10 \mathrm{~cm}\right)$. Soil samples were taken with a shovel and sieved on site using a $2 \mathrm{~mm}$ mesh size for chemical characterization. One additional soil sample per point was taken with a $100 \mathrm{~cm}^{3}$ steel cylinder for determination of bulk density. These samples were dried at $70{ }^{\circ} \mathrm{C}$ for at least $2 \mathrm{~d}$ and then weighted and referred to sample volume.

Soil extraction of ammonium and nitrate proceeded with a $0.021 \mathrm{~mol} \mathrm{~L}^{-1}$ of aluminum potassium sulfate dodecahydrate (Merck, Darmstadt, Germany, $\left.\mathrm{KAl}\left(\mathrm{SO}_{4}\right)_{2} * 12 \mathrm{H}_{2} \mathrm{O}\right)$ solution $(1: 4 \mathrm{~m} / \mathrm{v})$ and determined by means of fractionated steam distillation (Pérez et al., 1998). In order to estimate soil C lability, we used the $\mathrm{C} / \mathrm{N}$ ratio of soil organic matter assuming that lower soil $\mathrm{C} / \mathrm{N}$ ratio indicated higher $\mathrm{C}$ lability. Soil samples were ground for the determination of total $\mathrm{N}$ and $\mathrm{C}$ by means of flash combustion with and element analyzer (NA 2500 Carlo Erba Element Analyzer, Lakewood, New Jersey, USA). Soil reaction was determined in a 1:4 soil:water suspension with a glass electrode (Horiba, Kyoto, Japan). This proportion was used considering the high amount of organic matter in theses soils.

Parallel to these analyses, four soil cores of the surface horizon $(\mathrm{Ah})$ were taken with a $100 \mathrm{~cm}^{3}$ steel cylinder in each sample point for the determination of 
denitrification rates by the acetylene inhibition assay (Groffman et al., 1999). Net nitrification and nitrate concentration in these soils are high (Pérez et al., 2009) and therefore nitrate reductase inhibition by acetylene is minimal. Soil cores were carefully placed inside 500 $\mathrm{mL}$ hermetic glass jars and stored for up to $6 \mathrm{~h}$ before incubation at room temperature $\left(16\right.$ to $\left.22^{\circ} \mathrm{C}\right)$. These jars are sealed with a canning lid fitted with a rubber stopper. Before experimental treatment, soil cores were vented to equilibrate with ambient atmosphere. From the four soil cores, one was added $4 \mathrm{~mL} 0.7 \mathrm{mmol} \mathrm{NO}_{3}-\mathrm{N}$ from a potassium nitrate $\left(\mathrm{KNO}_{3}\right.$, Fluka, Buchs, Switzerland) solution (AN), and a second sample was added the same $4 \mathrm{~mL}$ of the nitrate solution plus $4 \mathrm{~mL}$ of a $23.3 \mathrm{mmol}$ C-glucose (D- $\mathrm{C}_{6} \mathrm{H}_{12} \mathrm{O}_{6}$, Vetec, Rio de Janeiro, Brazil) solution (ANG). Two soil cores were left untreated as controls. As the addition of either 4 or $8 \mathrm{~mL}$ of water did not significantly change water content of soils in both forests, control soil cores with distilled water were not considered. From the two controls cores, one was incubated without acetylene $(\mathrm{C})$, which allows estimating the reduction capacity of $\mathrm{N}_{2} \mathrm{O}$ to $\mathrm{N}_{2}$. The second control with acetylene (A) allows the accumulation of $\mathrm{N}_{2} \mathrm{O}$ to measure it by gas chromatography. A $10 \% \mathrm{v} / \mathrm{v}$ acetylene atmosphere was created in the nutrient addition soil cores and in the (A) control soil core. Gas samples were taken with plastic syringes and needles stuck into the rubber stopper, at 0,2 and $6 \mathrm{~h}$ of incubation and stored in $3 \mathrm{~mL}$ Venojets (Terumo, Leuven, Belgium). Samples were frozen until analyzed. The $\mathrm{N}_{2} \mathrm{O}$ concentration in the gas samples was determined by gas chromatography (Shimadzu GC 8A, Kyoto, Japan), equipped with a Porapack column Q 80/100 and electron capture detector. Carrier gas used was a mixture of methane and argon. Calibration curves were prepared with a 1 $\mathrm{mg} \mathrm{L}^{-1}$ nitrous oxide balance in $\mathrm{N}$ of Scotty analyzed gases. Denitrification rates were estimated from $\mathrm{N}_{2} \mathrm{O}-\mathrm{N}$ concentration difference between 6 and $2 \mathrm{~h}$ of incubation and referred to an area basis. All analyses were conducted at the Biogeochemistry Laboratory in the Pontificia Universidad Católica de Chile.

\section{Statistical analyses}

In order to test for the independency among sample points, the spatial autocorrelation of denitrification rates was estimated using Mantel's test (Manly, 1997). This test evaluates the correlation among the matrix of topographic distances among sample points and the matrix of differences in denitrification rates. The degree of significance of the correlation was tested using 999 permutations of a random matrix of differences in denitrification rates and comparing the observed correlation to the resulting null distribution
(Manly, 1997). Mantel's test was performed with the program PopTools (Hood, 2000). A non-significant correlation indicates statistical independence among sample points.

The effects of sampling date (months), logging treatment (forest type) and nutrient additions (nitrate and nitrate + glucose) on denitrification rates were assessed by a nested ANOVA considering repeated measures (Zar, 1996). One-way ANOVA and a posteriori Tukey's tests were used to identify differences soil characteristics between logged and unlogged forests. When the assumption for variance homogeneity was not fulfilled, data were either log transformed or ranked. Forward stepwise multiple regressions were used to detect the soil variable responsible for denitrification rates: e.g.; soil $\mathrm{pH}$, bulk density, water content, $\mathrm{C} / \mathrm{N}$ ratio, nitrate and ammonium content. Statistical analyses were performed with the program Statistica 5.1 (Statsoft, 1997). P values were significant at 0.05 level.

\section{RESULTS AND DISCUSSION}

The correlation coefficient of Mantel's test was nonsignificant $(\mathrm{r}=0.021, \mathrm{P}=0.731)$, indicating a spatial independence among soil sample points in both logged and unlogged forests. Surface soils of logged and oldgrowth forests did not significantly differ in most chemical properties and bulk density, but ammonium and water content were higher in the logged forest (Table 1). Denitrification rates in unlogged and logged forests were significantly correlated with soil nitrate content $\left(\mathrm{r}^{2}=0.594, \mathrm{~F}_{2.9}=6.59, \mathrm{P}=0.017\right)$. A significant effect of logging $\left(\mathrm{F}_{1.38}=6.037, \mathrm{P}=0.019\right)$ and nutrient addition $\left(\mathrm{F}_{3.38}=27.26, \mathrm{P}<0.001\right)$ on denitrification rates was observed and no effect of sampling date was detected $\left(\mathrm{F}_{10.380}=0.061, \mathrm{P}=1\right)$. A-posteriori Tukey's tests indicate that: i) denitrification rates did not significantly differ between control cores with and without acetylene, and ii) the addition of nitrate and nitrate plus glucose significantly increased the rates of denitrification in logged and unlogged forest soils, showing an overall trend to be higher under selective logging (Figure 1). For all the interactive effects, it is worth mentioning that the 3-way interaction of silvicultural treatment $*$ nutrient addition * sampling date was not significant $\left(\mathrm{F}_{30.380}=0.511, \mathrm{P}=\right.$ 0.986 ) indicating that both logged and unlogged forests responded in the same way to nutrient addition in the different sampling periods. Averaging the values for all sampling dates, the increase in denitrification following nitrate plus glucose addition was one order of magnitude (Table 2) in both logged and unlogged forests.

Annual rates of denitrification estimated for these temperate forests during the study period were $1.3 \pm 0.4$ 
Table 1. Characterization of surface soils of unlogged, old-growth (OG) and selectively logged evergreen lowland rainforests of Chiloé Island, Chile.

\begin{tabular}{lcr}
\hline & Unlogged-OG & Logged \\
\hline $\mathrm{pH}\left(\mathrm{H}_{2} \mathrm{O}\right)$ & $4.8 \pm 0.08 \mathrm{a}$ & $4.9 \pm 0.11 \mathrm{a}$ \\
Bulk density, $\mathrm{g} \mathrm{cm}^{-3}$ & $0.34 \pm 0.03 \mathrm{a}$ & $0.26 \pm 0.03 \mathrm{a}$ \\
Water content, $\%$ & $59.93 \pm 1.1 \mathrm{a}$ & $73.22 \pm 2.58 \mathrm{~b}$ \\
$\% \mathrm{C}$ & $21.52 \pm 1.27 \mathrm{a}$ & $25.3 \pm 1.71 \mathrm{a}$ \\
$\% \mathrm{~N}$ & $1.44 \pm 0.09 \mathrm{a}$ & $1.54 \pm 0.06 \mathrm{a}$ \\
$\mathrm{C} / \mathrm{N}(\mathrm{w} / \mathrm{w})$ & $15.00 \pm 0.38 \mathrm{a}$ & $16.46 \pm 0.87 \mathrm{a}$ \\
$\mathrm{NH}_{4}-\mathrm{N}, \mathrm{mg} \mathrm{kg}^{-1}$ dry soil & $22.43 \pm 2.43 \mathrm{a}$ & $49.94 \pm 6.85 \mathrm{~b}$ \\
$\mathrm{NO}_{3}-\mathrm{N}, \mathrm{mg} \mathrm{kg}^{-1}$ dry soil & $11.35 \pm 4.38 \mathrm{a}$ & $19.67 \pm 4.69 \mathrm{a}$ \\
\hline
\end{tabular}

Different letters indicate significant differences according to Tukey tests $(\mathrm{P}<0.05)$. Average \pm standard error, $\mathrm{n}=6$ during 11 months .

$\mathrm{kg} \mathrm{N} \mathrm{ha}^{-1}$ in the unlogged old-growth forest and $5.4 \pm 3.8$ $\mathrm{kg} \mathrm{N} \mathrm{ha}{ }^{-1}$ in the logged forest. Peaks of denitrification were recorded during austral spring in old growth forest (October 2005 and 2007) and during austral summer (January 2007) in logged forest.

The lack of significant differences between control cores, i.e. with and without acetylene, suggests that in the first place, nitrate reductase was not inhibited by acetylene secondly, $\mathrm{N}_{2} \mathrm{O}$ is the main end product of denitrification, and thirdly, $\mathrm{N}_{2} \mathrm{O}$ accumulation in surface soil samples may be the product of both nitrification and denitrification.

Remarkable low values are obtained for bulk density in the $\mathrm{A}_{\mathrm{h}}$ horizon of logged and unlogged forests, but even lower values $\left(0.07 \mathrm{~g} \mathrm{~cm}^{-1}\right)$ were reported for montane oldgrowth forests of Chiloé Island (Zarin et al., 1998), which is explained by the high content of organic matter in these soils.

Extrapolating from our laboratory results to estimate of denitrification rates in the field must be taken with caution, because of important differences in temperature and other physical conditions. However, the extended sampling period of this study, which considered $3 \mathrm{yr}$ of seasonal sampling, provides a likely estimated of temporal variability of denitrifier populations in these southern forests. Annual rates of denitrification reported here were similar to those reported for other temperate forests, reaching 1.65 and $4.73 \mathrm{~kg} \mathrm{~N} \mathrm{ha}^{-1}$, and following the same tendency, from undisturbed and to logged forests, respectively (Barton et al., 1999). The trend to higher denitrification rates in selectively logged stands in Chiloé confirms other findings that logging promotes an increase of denitrification rates (Dutch and Ineson, 1990; Ineson et al., 1991; Griffiths and Swanson, 2001; Pu et al., 2001) associated with higher nitrate availability in disturbed soils (Robertson and Tiedje, 1988; Groffman and Tiedje, 1989; Wallenstein et al., 2006). Similarly, increased emissions of $\mathrm{N}_{2} \mathrm{O}-\mathrm{N}$ from soils (i.e. production of $\mathrm{N}_{2} \mathrm{O}$ from nitrification plus denitrification) have been detected in logged tropical rain forests of Malaysia (Yashiro et al., 2008). From our experimental evidence, the short-term addition of nitrate plus glucose significantly increased denitrification rates in both logged and unlogged forest, suggesting that both factors are limiting microbial activity. Similarly, labile $\mathrm{C}$ has enhanced denitrification when added together with nitrate to soils of northern temperate air-polluted and secondary forests (Struwe and Kjoller, 1989; Henrich and Haselwandter, 1991; Ashby et al., 1998). Consequently, nutrient pulses enhance denitrifiers activity in polluted as well in the less polluted southern temperate forests.

Our data suggests that gaseous losses of unreactive $\mathrm{N}$ may be an important pathway leading to nitrate loss from forest soils and reduced nitrate losses to southern temperate forest streams, and hence they must be considered in modelling and balance approaches to understanding $\mathrm{N}$ transformations. We suggest that native denitrifiers in unpolluted old-growth forest soils are ready to act, e.g. genes can be readily expressed, when logging effects on organic matter decomposition increase the availability of $\mathrm{N}$ in the soil solution, loosing the documented tightness of the $\mathrm{N}$ cycle in these forests. As a consequence, logging of southern temperate lowland forests might not only affect soil sustainability, but also it can be a significant source of an intense greenhouse gas to the atmosphere.

\section{CONCLUSIONS}

Carbon lability, as estimated by soil $\mathrm{C} / \mathrm{N}$ ratios, did not significantly change with logging. In contrast, higher nitrogen availability in logged forest soils was expressed in higher soil ammonium content. The addition of nitrate plus glucose significantly increased denitrification rates in logged and unlogged forests suggesting that both nitrate and labile carbon are limiting denitrifiers activity in forest soils. Our short-term laboratory experiments suggest that the forest under selective logging have the potential for 

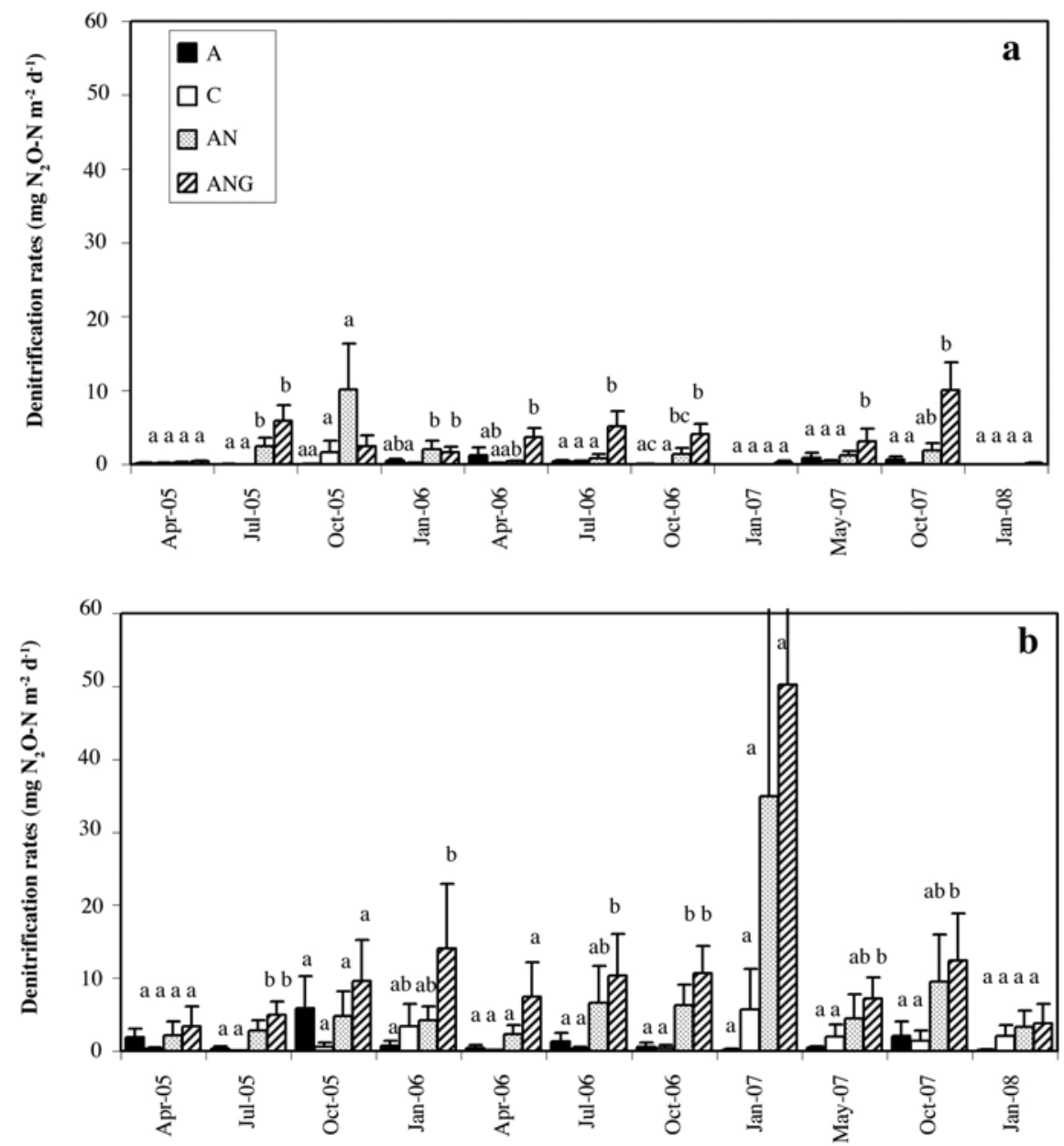

Average \pm standard error, $\mathrm{n}=6$. Different letters indicate significant differences among nutrient addition treatments according to Tukey's test $(\mathrm{P}<0.05)$.

Figure 1. Average denitrification rates measured in surface soil cores from lowland unlogged old-growth forest (a) and selectively logged forest (b), during 11 sampling dates. Cores were treated as follows: control without acetylene (C), control with acetylene (A), addition of 0.7 mmol $\mathrm{NO}_{3}-\mathrm{N}(\mathrm{AN})$, and addition of nitrate $\left(0.7 \mathrm{mmol} \mathrm{NO}_{3}-\mathrm{N}\right)$ plus 23.3 mmol C-glucose (ANG).

Table 2. Average denitrification rates measured in intact soil cores from unlogged, old growth (OG) and logged forests. Cores were treated as follows: control without acetylene $(C)$, control with acetylene $(A)$, addition of 0.7 mmol $\mathrm{NO}_{3}-\mathrm{N}(\mathrm{AN})$, and addition of nitrate $(0.7 \mathrm{mmol}$ $\mathrm{NO}_{3}-\mathrm{N}$ ) plus $23.3 \mathrm{mmol} \mathrm{C}$-glucose (ANG). Average \pm standard error, $n=6$ during 11 sampling dates.

\begin{tabular}{lcc}
\hline & \multicolumn{2}{c}{ Average denitrification rates } \\
\cline { 2 - 3 } & Unlogged-OG & Logged \\
\hline & \multicolumn{2}{c}{$\mu \mathrm{g} \mathrm{N}_{2} \mathrm{O}-\mathrm{N} \mathrm{m}^{-2} \mathrm{~d}^{-1}$} \\
$\mathrm{C}$ & $374 \pm 158$ & $1504 \pm 1287$ \\
$\mathrm{~A}$ & $1876 \pm 621$ & $1369 \pm 941$ \\
$\mathrm{AN}$ & $3353 \pm 451$ & $7403 \pm 4820$ \\
$\mathrm{ANG}$ & & $12192 \pm 7474$ \\
\hline
\end{tabular}

higher losses of $\mathrm{N}_{2} \mathrm{O}$ to the atmosphere. In a longer term, if selective logging significantly increases the content of nitrate and labile carbon in forest soils; i.e. lowering soil $\mathrm{C} / \mathrm{N}$ ratio, denitrification rates could be greatly stimulated.

\section{ACKNOWLEDGEMENTS}

Support for this study was provided by FONDECYT 1050830 (2005), FONDECYT-FONDAP 1501-0001 and Iniciativa Científica Milenio (P05-002). We thank the following people for allowing the access to the study sites: Javier Bruna, Arturo Gallardo, Elemías Gómez. This is a contribution to the research programs of Senda Darwin Biological Station and the Biogeochemistry laboratory at Pontificia Universidad Católica de Chile. 


\section{RESUMEN}

Efectos del nitrato y carbono lábil en la desnitrificación en suelos de bosques templados australes. La presión por el cambio en el uso del suelo y la tala de los bosques templados de Chile está aumentando rápidamente, con altos impactos potenciales sobre la capacidad de retención en el suelo de elementos limitantes del crecimiento y regeneración del bosque. Evaluamos las hipótesis que la tala selectiva del bosque incrementaría las tasas de desnitrificación y que la limitación de $\mathrm{N}$ y C para la actividad de los desnitrificadores sería más elevada en los bosques testigos que en los manejados. Las tasas de desnitrificación potencial se estimaron mediante el método de inhibición con acetileno en suelos intactos, a través de incubaciones de laboratorio a corto plazo, con los siguientes tratamientos: adición de $0.7 \mathrm{mmol}$ $\mathrm{N}-\mathrm{NO}_{3}$, nitrato más la adición de $23.3 \mathrm{mmol}$ C-glucosa, y controles con y $\sin 10 \% \mathrm{v} / \mathrm{v}$ acetileno. La tala selectiva no cambió significativamente la labilidad del $\mathrm{C}$ de la materia orgánica del suelo (e.g. $\mathrm{C} / \mathrm{N}$ ) ni el contenido de nitrato en el suelo. Un análisis de varianza anidado de dos factores para medidas repetidas muestra que las tasas de desnitrificación fueron estimuladas con la adición de nitrato más $\mathrm{C}$ lábil en ambos bosques, lo cual sugiere que en ambos tipos de bosque tanto el nitrato como el $\mathrm{C}$ lábil son limitantes de la actividad de los desnitrificadores. Los incrementos fueron de más de un orden de magnitud cuando la glucosa se agregó en los suelos tratados con

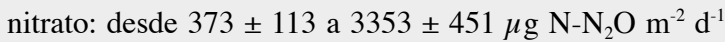
en los bosques testigos, y desde $1369 \pm 941$ a $12192 \pm$ $7474 \mu \mathrm{g} \mathrm{N}-\mathrm{N}_{2} \mathrm{O} \mathrm{m} \mathrm{m}^{-2} \mathrm{~d}^{-1}$ en el bosque bajo tala selectiva. Concluimos que las tasas de desnitrificación pueden estimularse en el largo plazo por la tala selectiva intensiva del bosque, debido a un incremento en la disponibilidad de nitrato y $\mathrm{C}$ lábil en el suelo perturbado.

Palabras clave: ensayo de inhibición con acetileno, bosques siempre verdes de zonas bajas, tala selectiva, disponibilidad de $\mathrm{N}$.

\section{LITERATURE CITED}

Armesto, J.J., C. Smith, M. Carmona, J.L. Celis, I. Díaz, A. Gaxiola, et al. 2009. Old-growth temperate rainforests of South America: Conservation, plantanimal interactions, and baseline biogeochemical processes. p. 367-390. In Wirth, C., G. Gleixner, and M. Heimann (eds.) Old-growth forests. Ecological studies 207. Springer Verlag, Berlin, Germany.
Ashby, J.A., W.B. Bowden, and P.S. Murdoch. 1998. Controls on denitrification in riparian soils in headwater catchments of a hardwood forest in the Catskill Mountains, USA. Soil Biol. Biochem. 30:853-864.

Barton, L., C.D. McLay, L.A Schipper, and C.T. Smith. 1999. Annual denitrification rates in agricultural and forest soils: a review. Aust. J. Soil Res. 37:1073-1093.

Brais, S., D. Paré, C. Camiré, P. Rochon, and C. Vasseur. 2002. Nitrogen net mineralization and dynamics following whole-tree harvesting and winter windrowing on clayed sites on northwestern Quebec. For. Ecol. Manage. 157:119-130.

Chatterjee, A., G.F. Vance, E. Pendall, and P.D. Stahl. 2008. Timber harvesting alters soil carbon mineralization and microbial community structure in coniferous forests. Soil Biol. Biochem. 40:1901-1907.

Decker, K., and R. Boerner. 2003. Elevation and vegetation influences on soil properties in Chilean Nothofagus forests. Rev. Chil. Hist. Nat. 76:371-381.

Diehl, P., M.J. Mazzarino, and S. Fontela. 2008. Plant limiting nutrients in Andean-Patagonian woody species: Effects of interannual rainfall variation, soil fertility and mycorrhizal infection. For. Ecol. Manage. 255:2973-2980.

Dutch, J., and P. Ineson. 1990. Denitrification of an upland forest site. Forestry 63:363-377.

Godoy, R., J. Haneke, J. Staelens, C. Oyarzún, L. Paulino, and M. Barrientos. 2005. Dry deposition of nitrogen to passive samplers in grassland and forest canopies in the central depression of southern Chile. Gayana Bot. 62:110-119.

Griffiths, R.P., and A.K. Swanson. 2001. Forest soil characteristics in a chronosequence of harvested Douglas-fir forests. Can. J. For. Res. 31:1871-1879.

Groffman, P.M., E.A. Holland, D.D. Myrold, G.P. Robertson, and X. Zou. 1999. Denitrification. p. 272288. In Robertson, G.P., D.C. Coleman, C.S. Bledsoe, and P. Sollins (eds.) Standard soil methods for long term ecological research. Oxford University Press, New York, USA.

Groffman, P.M., and J.M. Tiedje. 1989. Denitrification in north temperate forest soils:spatial and temporal patterns and the landscape and seasonal scales. Soil Biol. Biochem. 21:613-620.

Gutiérrez, A., J.J. Armesto, J.C. Aravena, M. Carmona, N. Carrasco, D. Christie, et al. 2009. Structural and environmental characterization of old-growth temperate rainforests of northern Chiloé Island, Chile: Regional and global relevance. For. Ecol. Manage. 258: 376-388. 
Henrich, M., and K. Haselwandter. 1991. Denitrifying potential and enzyme activity in a Norway spruce forest. For. Ecol. Manage. 44:63-68.

Henrich, M., and K. Haselwandter. 1997. Denitrification and gaseous nitrogen losses from an acid spruce forest soil. Soil Biol. Biochem. 29:1529-1527.

Hood, G.M. 2000. PopTools: Software for the analysis of ecological models. Available at http://www.cse.csiro. au/poptools/ (accessed January 2009).

Hope, G.D., C.E. Prescott, and L.L. Blevins. 2003. Responses of available soil nitrogen and litter decomposition to openings of different sizes in dry interior Douglas-fir forests in British Columbia. For. Ecol. Manage. 186:33-46.

Huygens, D., T. Rütting, P. Boeckx, O. Van Cleemput, R. Godoy, and C. Müller. 2007. Soil nitrogen conservation mechanisms in a pristine south Chilean Nothofagus forest ecosystem. Soil Biol. Biochem. 39:2448-2458.

Inagaki, Y., S. Kuramoto, A. Torii, Y. Shinomiya, and H. Fukata. 2008. Effects of thinning on leaf-fall and leaf-litter nitrogen concentration in hinoki cypress (Chamaecyparis obtusa Endlicher) plantations stands in Japan. For. Ecol. Manage. 255:1859-1867.

Ineson, P., J. Dutchand, and K.S. Killham. 1991. Denitrification in a Sitka spruce plantation and the effect of clear-felling. For. Ecol. Manage. 44:77-92.

Jordan, T.E., D.E. Weller, and D.L. Correl. 1998. Denitrification in surface soils of a riparian forest: Effects of water, nitrate and sucrose additions. Soil Biol. Biochem. 30:833-843.

Laverman, A.M., H.R. Zoomer, and H.A. Verhoef. 2001. The effect of oxygen, $\mathrm{pH}$ and organic carbon on soillayer specific denitrifying capacity in acid coniferous forest. Soil Biol. Biochem. 33:683-687.

Lindo,Z., and S. Visser. 2003. Microbial biomass, nitrogen and phosphorus mineralization, and mesofauna in boreal conifer and deciduous forest floors following partial and clear-cut harvesting. Can. J. For. Res. 33:1610-1620.

Manly, B.F. 1997. Randomization bootstrap and Monte Carlo methods in Biology. 399 p. Chapman \& Hall, London, UK.

Mohn, J., A. Schürmann, F. Hagedorn, P. Schleppi, and R. Bachofen. 2000. Increased rates of denitrification in nitrogen-treated forests soils. For. Ecol. Manage. 137:113-119.

Perakis, S., and L. Hedin. 2001. Fluxes and fates of nitrogen in soil of an unpolluted old-growth temperate forest, southern Chile. Ecology 82:2245-2260.
Pérez, C.A., M.R Carmona, and J.J. Armesto. 2003. Non-symbiotic nitrogen fixation, net nitrogen mineralization, and denitrification in evergreen forest of Chiloé Island, Chile: A comparison with other temperate forests. Gayana 60:25-33.

Pérez, C.A., L.O. Hedin, and J.J. Armesto. 1998. Nitrogen mineralization in two unpolluted old-growth forests of contrasting biodiversity and dynamics. Ecosystems 1:361-373

Pérez, C.A., M.R. Carmona, J.M. Fariña, J.J. Armesto. 2009. Selective logging of lowland evergreen rainforests in Chiloé Island, Chile: Effects of changing tree species composition on soil nitrogen transformations. For. Ecol. Manage. 258:1660-1668.

Prescott, C. 1997. Effects of clearcutting and alternative silvicultural systems on rates of decomposition and nitrogen mineralization in a coastal montane coniferous forest. For. Ecol. Manage. 95:253-260.

Pu, G., P.G. Saffigna, and Z. Xu. 2001. Denitrification, leaching and immobilization of ${ }^{15} \mathrm{~N}$-labelled nitrate in winter under windrowed harvesting residues in hoop pine plantations of 1-3 years old in subtropical Australia. For. Ecol. Manage. 152:183-194.

Regina, K., H. Nykänen, M. Maljanen, J. Silvola, and P.J. Martikainen. 1998. Emissions of $\mathrm{N}_{2} \mathrm{O}$ and $\mathrm{NO}$ and net nitrogen mineralization in a boreal forested peatland treated with different nitrogen compounds. Can. J. For. Res. 28:132-140.

Reynolds, P.E., N.V. Thevathasan, J.A. Simpson, A.M. Gordon, R.A. Lautenschlager, W.F. Bell, et al. 2000. Alternative forest release treatments affect microclimate and soil nitrogen mineralization. For. Ecol. Manage. 133:115-125.

Robertson, G.P., and J.M. Tiedje. 1988. Deforestation alters denitrification in a lowland tropical rain forest. Nature 336:756-758.

Robertson, G.P., P.M. Vitousek, P.A. Matson, and J.M. Tiedje. 1987. Denitrification in clearcut Loblolly pine (Pinus taeda L.) plantations in the southeastern US. Plant Soil 97:119-129.

Satti, P., M.J. Mazzarino, M. Gobbi, F. Funes, L. Roselli, and H. Fernandez. 2003. Soil N dynamics in relation to leaf litter quality and soil fertility in north-western Patagonian forests. J. Ecol. 91:173-181.

Statsoft. 1997. STATISTICA for Windows (Computer program manual). Version 5.0. Statsoft, Tulsa, Oklahoma, USA.

Struwe, S., and A. Kjoller. 1989. Field determination of denitrification in water logged forest soils. FEMS Microbiol. Ecol. 62:71-78. 
Thibodeau, L., P. Raymond, C. Camiré, and A.D. Munson. 2000. Impact of precommercial thinning in balsam fir stands on soil nitrogen dynamics, microbial biomass, decomposition and foliar nutrition. Can. J. For. Res. 30:229-238.

Vann, D.R., A. Joshi, C. Pérez, A.H. Johnson, J. Frizano, D.J. Zarin, and J.J. Armesto. 2002. Distribution and cycling of $\mathrm{C}, \mathrm{N}, \mathrm{Ca}, \mathrm{Mg}, \mathrm{K}$ and $\mathrm{P}$ in three pristine, old-growth forests in the Cordillera de Piuchué, Chile. Biogeochemistry 60:25-47.

Wallenstein, M.D., W.T. Peterjohn, and W.N. Schlesinger. 2006. Fertilization effects on denitrification and N cycling in an aggrading forest. Ecol. Appl. 16:21682176.
Yashiro, Y., W.R. Kadir, T. Okuda, and H. Koizumi. 2008. The effects of logging on soil greenhouse gas $\left(\mathrm{CO}_{2}\right.$, $\mathrm{CH}_{4}, \mathrm{~N}_{2} \mathrm{O}$ ) flux in a tropical rain forest, Peninsular Malaysia. Agric. For. Meteorol. 148:799-806.

Zar, J.H. 1996. Biostatistical analysis. $3^{\text {rd }}$ ed. 122 p. Prentice Hall, Upper Saddle River, New Jersey, USA. Zarin, D., A. Johnson, and S. Thomas. 1998. Soil organic carbon and nutrient status in old-growth montane coniferous forest watersheds, Isla Chiloé, Chile. Plant Soil 201:251-258. 